27. Zolotukhin D. What is memetic warfare and how does it threaten democratic values/ D. Zolotukhin//The crisis in Ukraine and information operations of the Russian Federation / Ed. by V. Ssazonov A. O. - Tartu, 2016.

28. Formyrovanye yazyka voiny $v$ Rossyy: kak y kohda eto nachalos. Access code: http://informburo.dn.ua/cgibin/iburo/start.cgi/www.haaretz.co.il/ opinions/www.kp.ru/online/\%20http:/thesame.tv/framevideo/start.cgi?info58=230 46\&page $=3$.

Lidia Smola, Dr. of Political Sc., Prof.

Igor Sikorsky National Polytechnic University of Kyiv, Kyiv, Ukraine
29. Popfalushi D. Rol i klasyfikatsiia memiv u ramkakh rosiisko-ukrainskoi viiny / D. Popfalushi. - Accesscode: http://iac.org.ua/rol-i-klasifikatsiyamemiv-u-ramkah-rosiysko-ukrayinskoyi-viyni/

Надійшла до редколегії 14.06.19

\title{
MEM AS A TOOL OF INFORMATION WAR
}

It is devoted to the problem of analyzing memes as a tool of information warfare. The article analyzes the history and origin of the study of memes as a phenomenon of information interaction and social technology. Memes can be interpreted as: image, idea, symbol, action, any cultural information copied by one person from another; the collective unconscious at the moment of acquiring verbal and visual form; specially created information message, which is distributed in the information space and is intended to form the necessary picture of the human world and make appropriate decisions. The meme influences the perception of reality and drives action. Different types, types of memes and their characteristics are considered. There is a diversity of spread of this phenomenon: global Internet memes, understandable to a wide range of people, and local memes that require specific awareness (gaming, hacking, scientific, professional). Emphasis is placed on the use of memes in contemporary armed conflicts. The information war, combined with the peculiarities of the modern information society, led to the use of new technologies to influence the mass consciousness, in particular, memetic weapons. The article analyzes memetic weapons as a technology of using memes for the distribution of beneficial information in the information space of the object of information confrontation. Particular attention was paid to the analysis of the perceptions of memes by ATO participants and volunteers. The urgency of the problem is determined by the need to analyze the impact of ideas reflected in Internet memes on the mass consciousness during the Russo-Ukrainian war. Within the framework of the Polish-Ukrainian project "Crisis Intervention - Support for NGOs in Ukraine Working with ATO Soldiers and Their Families", 20 flexible interviews were conducted.

The focus of the study may be to analyze the perception and functioning of political Internet memes on social media. Empirical studies of the influence of Internet memes on the structural components of the psyche of Internet users are also promising. The war in eastern Ukraine reaffirmed the paradigm shift of modern warfare, demonstrated the thoroughness of a thorough study of the phenomenon and the need to develop entirely new approaches to the realization of political and military goals. warfare.

Keywords: meme, idea, image, phenomenon, replicator, interactor, media virus, mind virus, communication, social consciousness, memetic

Лидия Смола, д-р полит. наук, профф.

НУ "Киевский политехнический университет имени Игоря Сикорского", Киев, Украина

\section{МЕМ КАК ИНСТРУМЕНТ ИНФОРМАЦИОННОЙ ВОЙНЫ}

Посвящена проблеме мема как инструмента информационной войны. Проанализирована история возникновения и генезис исследования мема как феномена информационного взаимодействия и социальной технологии. Рассмотрены различные типы, виды мемов и их характеристики. Акцентировано на разнообразии распространения этого феномена: глобальные интернет-мемы, которые понятны широкому кругу людей, и локальные мемы, требующие специфической осведомленности (геймерские, хакерские, научные, профессиональные). Отмечено использование мемов в современных вооруженных конфликтах. Мемы рассматриваются как современные единицы коммуникации. Интернет-мем может выполнять функции перевода, представления, информации, а также эмоционального и контактного общения. Меметическое оружие - это технология использования мемов для распространения полезной информации в информационном пространстве объекта информационного противоборства. Целью статьи является анализ влияния идей, отраженных в интернет-мемах, на массовое сознание во время вооруженной русско-украинской войны.

Ключевые слова: мем, идея, образ, феномен, репликатор, интерактор, медиа-вирус, вирус разума, коммуникация, социальное сознание, меметическая война.

Bulletin of Taras Shevchenko National University of Kyiv.

Series "Psychology". № 1(10), pp. 95-99 (2019)

УДК 159.9.01

DOI: https://doi.org/10.17721/BSP.2019.1(10).24
ISSN $1728-3817$

(C) Taras Shevchenko National University of Kyiv,

Publishing Center "Kyiv University", 2019

Олександр Ткаченко, канд. пед. наук, старш. наук. співроб.

Український фізико-математичний ліцей

Київського національного університету імені Тараса Шевченка, Київ, Україна

\section{ПРОЦЕДУРА СЕМАНТИКО-СМИСЛОВОГО АНАЛІЗУ ДОСЛІДЖЕННЯ РОЗВИТКУ АКМЕОРІЕНТОВАНОÏ ЗРІЛОÏ ОСОБИСТОСТІ}

Представлена така експериментальна процедура семантико-смислового аналізу наративів. 1. Семантичний аналіз - дозволяє визначити "семантичне поле" (СП), на основі якого формується відповідний "концентрований смисл" (КС). 2. Кореляційний аналіз - дозволяє визначити "загальне семантичне ядро" (ЗСЯ), коефіцієнти кореляції та "збіг" однакових слів. 3. Смисловий аналіз - передбачає створення "загального концентрованого смислу" (ЗКС) та "специфічного концентрованого смислу" (СКС), які використовуються у дослідженні та побудові моделей розвитку акмеорієнтованої зрілої особистості (АОЗО).

Ключові слова: наратив; смисл; акмеорієнтована зріла особистість (АОзО); семантичний аналіз; кореляційний аналіз; смисловий аналіз; семантичне поле; концентрований смисл; загальне семантичне ядро; специфічне семантичне ядро; загальний концентрований смисл; специфрічний концентрований смисл.

Постановка проблеми розвитку зрілої особистості розглядається у контексті ії̈ цілісно-цілеспрямованого представлення у вигляді узагальненої категорії справи життя (СЖ) і акмеорієнтованої зрілої особистості (АОЗО) як інтегративно-цілісне утворення, що обґрунтовано у роботах $[5 ; 6]$. Це утворення системно структурується на основі аксі-вектора вищих цінностей на дорефлексивному, рефлексивному і духовному рівнях та акме-вектора за етапами акмеорієнтації, акмування та новоутворення як прагнення до досягнення Ідеалу (свого вищого призначення) - реалізації "справи життя". Справа життя визначається як необхідна здатність учиняти задля розвитку особистості - утворення й підтримки динамічної цілісності її суб'єктності (першопричинності) і відповідної інтегральної здібності само- і життєздійснення [5, с. 46]. 
Основним предметом емпіричного дослідження розвитку АОЗО виявились смисли життя як практичні наративи, що потребувало створення відповідного інструментарію.

Аналіз останніх досліджень і публікацій проводився на основі розуміння наративного методу у контексті психологічної герменевтики [1; 8], де основна увага приділялася смислам, що виходить на перший план у сучасній життєвій психології. Це дозволяє проникати у смисловий простір досліджуваного та визначати коди його виникнення, пережити багатогранність тексту й відкритість процесу означення, відслідковувати шляхи смислоутворення, виділяти індивідуальний смисл без претензій на якесь єдине узагальнення [1]. Ми приймаємо позицію авторів роботи [8] про те, що текстовий аналіз - це намагання визначити перебіг надтекстової організації значень та асоціативних полів, установлення кодів (типів баченого, прочитаного, зробленого тощо), які насамперед притаманні сфрері культури. Ми також розглядаємо наративний текст як засіб організації й упорядкування особистого досвіду, який твориться у конкретній життєвій, насамперед практичній кризовій ситуації, що дозволяє виявити сам процес усвідомлення власного життєвого досвіду як наративну особистість.

Це дозволяє розглядати текст як об'єкт психологічного дослідження, коли він стає центральною ланкою комунікативного ланцюга "автор - повідомлення - реципієнт" та пропонує вивчення його з позицій характеристик, які "стягують" крайні полюси цієї комунікації, забезпечуючи породження та синтез нового смислу (як новоутворення), збагачуючи як особистий досвід "реципієнта", так і його внесок як наповнення (модус) культури. Для опрацювання текстових матеріалів основна увага приділялась смисловій динаміці у контексті доцільності побудови життя на основі набутих нових морально-етичних цінностей у ході переживання критичних ситуацій, що особливо стало актуальним в умовах бойових дій і після повернення з війни. Нас насамперед цікавили не стільки онтологічні, на яких акцентує увагу Т. А. Ван-Дейк [2], скільки аксіологічні смисли. Скориставшись ідеєю смислового моделювання цього автора, для такого аналізу було розроблено спеціальну експериментальну процедуру, яка дозволяє виявляти поряд із онтологічними, і аксіологічні смисли, де ключовою ланкою стає експерт, який відповідає вимогам розвитку $\mathrm{AO} 3 \mathrm{O}$.

Невирішеною раніше частиною даної проблеми $\epsilon$ недостатній рівень розробки експериментального інструментарію, який дозволяє виявляти аксіологічні смисли.

Мета статті полягає у розробці та представленні експериментальної процедури семантико-смислового аналізу як інструменту емпіричного дослідження розвитку АОЗО.

Виклад основного матеріалу. Як досліджувані наративи використовувались найбільш автентичні матеріали, які характеризують життя людини як особистісні переживання: автобіографрічні тексти (для аналізу життя в цілому); спеціальні звіти-одкровення за авторською експериментальною методикою, які передбачали повну правдивість і почуттєво-емоційну відкритість (для аналізу окремих життєвих ситуацій) [5, с. 124-125]; модифікований варіант стандартизованої методики незакінчених речень за опитувальником Ж. Нюттена в адаптації М. Ш. Магомед-Емінова [3] (для порівняльного аналізу в різних життєвих умовах); для статистичної обробки отриманих результатів застосовувалась програма SPSS-версії 19.0.

У цій статті процедура семантико-смислового аналізу представлена на прикладі однієї з найнапруженіших ситуацій (перший бій) бойових дій (БД) у ході антитерористичної операції (АТО), коли основна увага приділяється аксіологічним життєвим смислам. В інших дослідженнях вона також широко використовувалась для визначення й порівняння семантико-смислових характеристик текстів, які відображали окремі життєві ситуації, життєві періоди та життя в цілому, пов'язані 3 дослідженням концептуальної моделі розвитку АОЗО. Ця процедура включала таку технологічну послідовність семантичного, кореляційного та смислового аналізу наративних текстів.

Семантичний аналіз текстів, поданих в автентичному варіанті мовою досліджуваного, проводиться за допомогою відповідної стандартної комп'ютерної програми [4]. Для аналізу використовуються наративи звітів-одкровень досліджуваних, отриманих у бойових умовах (БД) безпосередньо в зоні бойових дій незадовго після бою, та в мирних умовах (мир) через рік і більше після повернення 3 війни як ветерана. Особлива увага звертається на аналіз тексту за законом Ципфа [8] 3 відповідною кількісною характеристикою ("входження") частоти найуживаніших слів. Це дозволяє отримати незалежну від дослідника об'єктивну картину семантичного масиву аналізованого тексту.

Загальну семантичну характеристику тексту наративів першого бою в бойових (БД) та мирних (мир) умовах представлено в табл. 1

Результати комп'ютерного аналізу подано в автентичному варіанті в табл. 2 (БД) та табл. 3 (мир).

Це дозволяє із визначеного семантичного масиву в автоматичному режимі виокремити відповідне "семантичне поле" (СП) слів (виділено жирним шрифтом). На основі такого СП, за необхідності, компетентним експертом (чи самим дослідником) формується відповідний "концентрований смисл" (КС).

Кореляційний аналіз і аналіз збігу проводиться на основі порівняння СП аналізованих текстів, поданих у табл. 2 та 3. При цьому не беруться до уваги значення, які не мають смислового навантаження, такі, як "i", "що", повтори тощо (у таблицях виділені курсивом нежирним шрифтом). Основною статистичною характеристикою слова визначається кількість "входжень" (фактична або "за Ципфом"). Порівняльну картину СП щодо першого бою у бойових та мирних умовах представлено у табл. 4.

Загальна семантична характеристика тексту наративів першого бою в бойових (БД) та мирних (мир) умовах

\begin{tabular}{|l|c|c|}
\hline \multicolumn{1}{|c|}{ Параметр } & Значення (БД) & 3начення (мир) \\
\hline Кількість символів із пробілами & 3344 & 5122 \\
\hline Кількість символів без пробілів & 2839 & 4343 \\
\hline Кількість слів & 530 & 810 \\
\hline Якість тексту за законом Ципфа & $57 \%$ & $44 \%$ \\
\hline
\end{tabular}

Аналіз тексту наративів першого бою в бойових умовах (БД)

Таблиця 2

\begin{tabular}{|c|l|c|c|}
\hline № п/п & \multicolumn{1}{|c|}{ Слово (БД) } & Входжень & 3а Ципфом \\
\hline 1 & Быть (был, была, были, было, будь) & 13 & 13 \\
\hline 2 & Бой (бой, бою, боя) & 13 & 7 \\
\hline 3 & Весь (все, всей, всему, всем, всех) & 12 & 5 \\
\hline
\end{tabular}




\begin{tabular}{|c|c|c|c|}
\hline № $\boldsymbol{n} / \boldsymbol{n}$ & Слово (БД) & Входжень & За Ципфом \\
\hline 4 & Первый (первых, первый, первому, первого,первые, первыми, первом) & 10 & 4 \\
\hline 5 & Мой (мое, моего, моих, моя) & 5 & 3 \\
\hline 6 & Страх (страх, страха) & 5 & 3 \\
\hline 7 & $\mu_{0}$ & 4 & 2 \\
\hline 8 & Смерть (смерть, смерти) & 3 & 2 \\
\hline 9 & Который (которые, который) & 3 & 2 \\
\hline 10 & Свій (свои, свою, своих) & 3 & 2 \\
\hline 11 & жизнь & 3 & 2 \\
\hline 12 & $i$ & 3 & 2 \\
\hline 13 & паніка & 2 & 1 \\
\hline 14 & Опасность (опасность, опасности) & 2 & 1 \\
\hline 15 & Бывать (бывает, бывают) & 2 & 1 \\
\hline 16 & Разный (разному, разные) & 2 & 1 \\
\hline 17 & Товариш (товарищах, товарищей) & 2 & 1 \\
\hline 18 & було & 2 & 1 \\
\hline 19 & вести & 2 & 1 \\
\hline 20 & був & 2 & 1 \\
\hline
\end{tabular}

Аналіз тексту наративів першого бою в мирних умовах (мир)

таблиця 3

\begin{tabular}{|c|l|}
\hline № п/п & \multicolumn{1}{c}{ Слово (мир) } \\
\hline 1 & Быть (было, был, были, была) \\
\hline 2 & Страх (страх, страха) \\
\hline 3 & Первый (первый, первого, первые, первое, первая) \\
\hline 4 & Весь (весь, все, всю) \\
\hline 5 & Обстрел (обстрелы, обстрел, обстрела) \\
\hline 6 & Человек (людей, человека, человек) \\
\hline 7 & що \\
\hline 8 & Бой (бой, боя, бою) \\
\hline 9 & Думать (думал, думать, думаю, думав) \\
\hline 10 & Пацан (пацаны, пацанами) \\
\hline 11 & це \\
\hline 12 & Мочь (могут, могу, мог) \\
\hline 13 & День (день, дня, дней) \\
\hline 14 & Свій (своих, свой, своим, свое) \\
\hline 15 & Адреналин (адреналин, адреналина) \\
\hline 16 & Ребята (ребята, ребят) \\
\hline 17 & після \\
\hline 18 & було \\
\hline 19 & почему \\
\hline 20 & заканчиваться \\
\hline
\end{tabular}

\begin{tabular}{|c|c|}
\hline Входжень & За Ципфом \\
\hline 14 & 14 \\
\hline 11 & 7 \\
\hline 11 & 5 \\
\hline 9 & 4 \\
\hline 7 & 3 \\
\hline 7 & 3 \\
\hline 7 & 2 \\
\hline 5 & 2 \\
\hline 4 & 2 \\
\hline 4 & 2 \\
\hline 4 & 2 \\
\hline 4 & 2 \\
\hline 4 & 2 \\
\hline 4 & 1 \\
\hline 4 & 1 \\
\hline 3 & 1 \\
\hline 3 & 1 \\
\hline 3 & 1 \\
\hline 3 & 1 \\
\hline 3 & 1 \\
\hline
\end{tabular}

Tаблиця 4

Порівняльний аналіз тексту наративів першого бою в бойових (БД) та мирних (мир) умовах за кількістю "входжень"

\begin{tabular}{|c|c|c|c|}
\hline № $\boldsymbol{n} / \mathbf{n}$ & 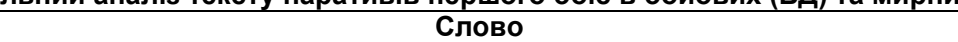 & Входжень (БД) & Входжень (мир) \\
\hline 1 & Быть (был, была, были, было, будь) & 13 & 14 \\
\hline 2 & Бой (бой, бою, боя) & 13 & 5 \\
\hline 3 & Весь (все, всей, всему, всем, всех) & 12 & 9 \\
\hline 4 & Первый (первых, первый, первому, первого, первые, первыми, первом) & 10 & 11 \\
\hline 5 & Страх (страх, страха) & 5 & 11 \\
\hline 6 & Свій (свои, Свою, Своих) & 3 & 4 \\
\hline 7 & $\begin{array}{l}\text { Товариш (товарищах, товарищей); пацан (пацаны, пацанами); } \\
\text { ребята (ребята, ребят) }\end{array}$ & 2 & 4 \\
\hline 8 & мой (мое, моего, моих, моя) & 5 & \\
\hline 9 & смерть (смерть, смерти) & 3 & \\
\hline 10 & который (которые, который) & 3 & \\
\hline 11 & жизнь & 3 & \\
\hline 12 & паніка & 2 & \\
\hline 13 & опасность (опасность, опасности) & 2 & \\
\hline 14 & бывать (бывает, бывают) & 2 & \\
\hline 15 & разный (разному, разные) & 2 & \\
\hline 16 & вести & 2 & \\
\hline 17 & обстрел (обстрелы, обстрел, обстрела) & & 7 \\
\hline 18 & человек (людей, человека, человек) & & 7 \\
\hline 19 & думать (думал, думать, думаю, думав) & & 4 \\
\hline 20 & пацан (пацаны, пацанами) & & 4 \\
\hline 21 & мочь (могут, могу, мог) & & 4 \\
\hline 22 & день (день, дня, дней) & & 4 \\
\hline 23 & адреналин (адреналин, адреналина) & & 4 \\
\hline 24 & після & & 3 \\
\hline 25 & почему & & 3 \\
\hline 26 & заканчиваться & & 3 \\
\hline
\end{tabular}

Примітки: ЗСЯ - жирний шрифт; ЗКС - курсив жирним шрифтом; ССЯ - нежирний шрифт; СКС - курсив нежирним шрифт

Слова, які збіглися в обох порівнюваних семантичних масивах СП (виділені жирним шрифтом), становили "загальне семантичне ядро" (ЗСЯ), яке бралося до ува- ги для визначення кореляції за Спірменом ( $\rho)$ чи за Пірсоном (r). Також виявлявся показник "збігу" (C, від 0 до 1) як відношення кількості слів, що збіглися в обох 
порівнюваних СП до загальної кількості позицій (слів) в одній таблиці. Слова, які не збіглися у кожному із порівнюваних СП (не виділені жирним шрифтом), становили "специфічне семантичне ядро" (ССЯ).

Результати кореляційного аналізу як за Пірсоном $\left(r=-0,06\right.$ при $\left.r_{\text {крит }}=0,67, p=0,05 ; r_{\text {крит }}=0,80, p=0,01\right)$, так і за Спірменом ( $\rho=0,616$ при $p>0,05)$ показали відповідно "відсутність" і "не значущість"кореляції між порівнюваними семантичними масивами СП за збігу
$\mathrm{C}=35$ (умовно вважається, що виражений показник "збігу" має становити 0,50 і більше).

Смисловий аналіз здійснюється експертом (чи експериментатором) на основі ЗСЯ й ССЯ як його індивідуальне розуміння. У результаті утворюється спільний для обох СП "загальний концентрований смисл" (ЗКС) і окремо для кожного СП "специфрічний концентрований смисл" (СКС). Результати семантичного та смислового аналізу першого бою подано у табл. 5 .

Результати семантичного та смислового аналізу першого бою

\begin{tabular}{|c|c|c|}
\hline Група & Код & Слова, смисли \\
\hline \multirow[t]{2}{*}{ заг. } & 3ся & бути, страх, перший, весь, бій, свій, пацани, хлопці, товариші \\
\hline & 3КС & Весь перший бій був страх за своїх пацанів, хлопців, товаришів \\
\hline \multirow[t]{2}{*}{ БД } & ССЯ & смерть, який, життя, мій, паніка, небезпека, бувати, різне, вести, був, було \\
\hline & СКC & $\begin{array}{l}\text { Весь перший бій був страх за своїх пацанів, хлопців, товаришів. У моєму житті бувало різне. } \\
\text { Була небезпека паніки, яка вела до смерті }\end{array}$ \\
\hline \multirow[t]{2}{*}{ мир } & ССЯ & обстріл, людина, думати, могти, адреналін, після, було, чому, закінчуватись \\
\hline & СКС & $\begin{array}{l}\text { Весь перший бій був страх за своїх пацанів, хлопців, товаришів. Після обстрілу адреналін закін- } \\
\text { чувався і людина могла день думати чому (що) це було }\end{array}$ \\
\hline
\end{tabular}

Особливу увагу слід звертати на підбір особистості експерта як гарантію продукування разом із онтологічними й аксіологічними смислами. Він має відповідати, як мінімум, таким вимогам: наявність достатнього власного травматичного досвіду переживання критичних ситуацій (у даному випадку перебування в бойових та мирних умовах); наявність чітко вираженої морально-етичної домінанти розвитку власної особистості як АОЗО.

Як бачимо, СКС у діючих воїнів-захисників в умовах БД та ветеранів в умовах миру суттєво відрізняється. До того ж відсутня (не значуща) кореляція й не виражений "збіг" між ними. Поряд із цим смисловий аналіз (табл. 5) засвідчив, що на фоні загального усвідомлення страху за інших, у бійців на передовій розуміння першого бою було спрямоване безпосередньо на осмислення загрози життю (небезпеки, паніки, смерті). Натомість у мирних умовах таке розуміння вже стало більш глибоким, спрямованим на осмислення суті та смислу того, що відбувалось. Усе це свідчить про значну різницю в осмисленні війни із плином часу навіть у самих учасників бойових дій. Більш повне осмислення починає з'являтись уже після повернення їх як ветеранів. Такий висновок дозволяє створити об'єктивну картину подальшого життєздійснення та розвитку особистості.

Висновки. Запропонована процедура семантикосмислового аналізу наративів виявилась ефективним інструментом у дослідженні розвитку АОЗО.

1. 3 одного боку, вона складається зі стандартизованих методик, що дозволяє говорити про валідність і надійність. 3 іншого боку, у комплексі застосування цих методик та завдяки індивідуальному узагальненню за допомогою компетентного експерта вдається отримати якісно новий результат у вигляді аксіологічних смислів.

2. Застосування даної експериментальної процедури в умовах бойових дій показало наявність ефективного інструменту психологічного дослідження у кризових ситуаціях.

У перспективі подальших досліджень це дозволяє: проводити подальшу апробацію концептуальної моделі розвитку АОЗО та емпірично виявляти її струк- туру й відповідну типологію; за рахунок використання більш потужних і спеціалізованих комп'ютерних програм семантичного аналізу текстів значно розширювати об'єми емпіричних досліджень розвитку АОЗО в бік акмесоціалізації; розширювати проблематику дослідження психології особистості у критичних ситуаціях.

Список використаних джерел

1. Барт Р. Мифологии / Р. Барт // Избранные работы. - М., 1989

2. Ван-Дейк Т. А. Язык. Познание. Коммуникация / пер. с англ. - М. : Прогресс, 1989. - 312 с.

3. Квасова О. Г. Трансформация временной перспективы личности в экстремальной ситуации: дис. ... канд. психол. наук: $19.00 .01 /$ О. Г. Квасова. - М., 2013. - 216 с.

4. Полный семантический анализ текста онпайн (seo-анализ) [Електронний ресурс]. - Режим доступу: https://miratext.ru/seo_analiz_text.

5. Ткаченко О. Справа життя: умова розвитку зрілої особистості: моногр. / Олександр Ткаченко. - Київ : ЦП "КОМПРИНТ", 2018. - 332 с.

6. Ткаченко О. А. Методологічні принципи розвитку акмеорієнтованої зрілої особистості / О. А.Ткаченко // Психолог. часопис. - 2019. - № 2(22). С. 148-163. - Режим доступу: https://doi.org/10.31108/1.2019.2.22.

7. Чепелева Н. В. Проблемы психологической герменевтики / Н. В. Чепелева. - К. : Изд-во нац. пед. ун-та им. Н. П. Драгоманова, 2009. -382 c.

8. Zipf G. K. Human Behaviorand the Principle of Least Effort. - AddisonWesleyPress, 1949. - C. 484-490. - 573 p

\section{References}

1. Bart R. Izbrannye raboty / Mifologii / Mif segodnya. - M., 1989.

2. Van Dejk T. A. Yazyk. Poznanie. Kommunikaciya / Per. s angl. - M. : Progress, 1989. $-312 \mathrm{~s}$

3. Kvasova O. G. Transformaciya vremennoj perspektivy lichnosti v ekstremalnoj situacii: dis. ... kand. psiholog. nauk: 19.00.01/ O. G. Kvasova. - M., 2013. -216 s.

4. Polnyj semanticheskij analiz teksta onlajn (seo-analiz): resurs https://miratext.ru/seo analiz text.

5. Tkachenko O. Sprava zhittya: umova rozvitku zriloyi osobistosti. Monografiya / Oleksandr Tkachenko. - Kiyv : CP "KOMPRINT", 2018. - 332 s.

6. Tkachenko O. A. Metodologichni principi rozvitku akme-oriyentovanoyi zriloyi osobistosti / O. A. Tkachenko// Psihologichnij chasopis. - 2019. № 2(22). - S. 148-163. - Rezhim dostupu: https://doi.org/10.31108/1.2019.2.22.

7. Chepeleva N. V. Problemy psihologicheskoj germenevtiki / N. V. Chepeleva. - K.: Izdatelstvo Nacionalnogo pedagogicheskogo universiteta im. N. P. Dragomanova, 2009. - $382 \mathrm{~s}$.

8. Zipf G. K. Human Behavior and the Principle of Least Effort. Addison-Wesley Press, 1949. - S. 484-490. - 573 s.

Надійшла до рекголегії 15.05.19

Oleksandr Tkachenko, PhD, practical psychologist

Ukrainian Physics and Mathematics Lyceum of Taras Shevchenko National University of Kyiv, Kyiv, Ukraine

\section{PROCEDURE OF SEMANTIC-SENSE ANALYSIS OF THE RESEARCH OF THE DEVELOPMENT} OF AKME-ORIENTED MATURE PERSONALITY

The development of a mature personality is considered in the context of its holistic and purposeful presentation in the form of a generalized category of the work of life and an acme-oriented mature personality, as an integrative-holistic entity. This education is systematically structured on the basis of the Axi-vector of higher values at the pre-reflexive, reflective and spiritual levels and the acme vector according to the stages of acme orientation. The article presents the procedure of the semantic-sense analysis of the research of the development of akme-oriented mature 
personality. The following experimental procedure for semantic-sense analysis of narratives is presented. 1) Semantic analysis, which allows to identify the "semantic field" (SF) and form a "concentration sense" (CS). 2) Correlation analysis, which makes it possible to single out the "common semantic core" (CSC), to determine the correlation coefficient, as well as the "coincidence" of identical words. 3) Sense analysis, which envisages the creation of a "common concentrated sense" (CCS) and a "specific concentrated sense" (SCS), which was used in the study of the development and formation of the model acme-oriented mature personality (AOMP).

The article deals with the procedure of semantic-semantic analysis on the example of one of the most stressful situations (the first battle) of combat operations (DB) under counter-terrorism operation (ATO), when the focus is on axiological meanings. The proposed procedure for semantic-semantic analysis of narratives is an effective tool that consists of standardized techniques that are valid and reliable. Also, the complex application of these methods, and thanks to individual generalization with the help of a competent expert, can produce a qualitatively new result in the form of axiological meanings. This makes it possible to conduct an experimental procedure in combat and is, in turn, an effective tool for psychological research in crisis situations. Therefore, the results presented in the article are an achievement that is of practical importance, both for peer review and for the purpose of psychotherapy.

Keywords: narrative; sense; acme-oriented mature personality; semantic analysis; correlation analysis; sense analysis; semantic field; concentrated sense; common semantic core; specific semantic core; common concentrated sense; specific concentrated sense.

Александр Ткаченко, канд. пед. наук, старш. науч. сотрудник

Украинского физико-математического лицей

Киевского национального университета имени Тараса Шевченко, Киев, Украина

\section{ПРОЦЕДУРА СЕМАНТИКО-СМЫСЛОВОГО АНАЛИЗА ИССЛЕДОВАНИЯ РАЗВИТИЯ АКМЕОРИЕНТИРОВАННОЙ ЗРЕЛОЙ ЛИЧНОСТИ}

Представлена следующая экспериментальная процедура семантико-смыслового анализа нарративов. 1. Семантический анализ, позволяющий выделить "семантическое поле" (СП) и сформировать "концентрованый смысл" (КС). 2. Корреляционный анализ, позволяющий определить "общее семантическое ядро" (ОСЯ), коэфффициент корреляции, также "совпадение" одинаковых слов. 3. Смысловой анализ предусматривает создание "общего концентрированного смысла" (ОКС) и "специфического концентрованного смысла" (СКС), которые используются при исследовании и формировании моделей развития акмеориентированной зрелой личности (АОЗЛ).

Ключевые слова: нарратив; смысл; акмеориентированная зрелая личность (АОЗЛ); семантический анализ; корреляционный анализ; смысловой анализ; семантическое поле; концентрированный смысл; общее семантичнеское ядро; специфическое семантическое ядро; общий концентрированный смысл; специфический концентрованный смысл.

Bulletin of Taras Shevchenko National University of Kyiv. Series "Psychology". № 1(10), pp. 99-103 (2019) УдК 159.9:304.9

DOI: https://doi.org/10.17721/BSP.2019.1(10).25
ISSN 1728-3817

(C) Taras Shevchenko National University of Kyiv, Publishing Center "Kyiv University", 2019

Кирило Тулін, психолог Київ, Україна

\section{СОЦІАЛЬНО-ПСИХОЛОГІЧНІ ЧИННИКИ АКТИВНОСТІ ТЕРИТОРІАЛЬНИХ ГРОМАД В УМОВАХ ДЕЦЕНТРАЛІЗАЦІї}

Досліджено соціально-психологічні чинники активності територіальних громад в умовах децентралізації. 3'ясовано низку проблем, які стимулювали підвищення активності територіальних громад. Проаналізовано динаміку збільшення кількості ОТГ у 2015-2018 рр. у всіх областях України. Розелянуто, що фрінансова децентралізація також стала одним із основних фракторів підвищення активності населення. Зазначено, що значна частина населення територіальних громад готова брати участь у громадських заходах.

Ключові слова: активність, територіальна громада, децентралізація, фінансова децентралізація, самоорганізація населення, громадські заходи.

Актуальність проблеми дослідження. В Україні набуває розвитку процес децентралізації влади, звільнення держави від невластивих для неї фрункцій регулювання всіх боків суспільного життя, становлення громадянського суспільства на засадах розвитку Інституту місцевого самоврядування. Підвищення рівня спроможності виконання наданих місцевому самоврядуванню повноважень здійснюється шляхом об'єднання територіальних громад, створення трирівневої системи "громада-район-регіон" зі збалансованою тріадою "відповідальність - ресурси - повноваження". Але в умовах децентралізації жодна урядова стратегія чи політика не сприятиме реальному розвитку таким чином, як активна і відповідальна позиція місцевих громад.

Аналіз останніх досліджень і публікацій. Вивченням теоретичних та практичних питань децентралізації влади і розвитку місцевого самоврядування займаються вітчизняні й зарубіжні вчені: В. Авер'янов, В. Бакуменко, О. Бориславська, М. Братковський, І. Грицяк, К. Линьов, А. Матвієнко, В. Мельниченко, Н. Мельтюхова, О. Петренко, Шемшученко. Соціальні інновації залучення селян до колективних дій, становлення сільських громад у процесі соціальної взаємодії та їхня роль у сільському розвитку досліджує О. Бородіна. Проте, не зважаючи на активну наукову роботу, питання соціально-психологічних чинників активності територіальних громад в умовах децентралізації залишається актуальним та потребує досліджень.

Мета та завдання. Розглянути основні аспекти соціально-психологічних чинників активності територіальних громад в умовах децентралізації. Мета дослідження проаналізувати соціально-психологічні чинники активності територіальних громад в умовах децентралізації. Об'єкт дослідження - чинники активності територіальних громад в умовах децентралізації. Предмет дослідження - активність територіальних громад.

Виклад основного матеріалу. В Україні адміністративна децентралізація виявляється в тому, що за державою зберігається право охорони та забезпечення загальнодержавних інтересів, які здійснюються через утворення централізованої системи відповідних органів державного управління на місцях (місцеві державні адміністрації, територіальні підрозділи центральних органів виконавчої влади). Натомість демократична децентралізація передбачає утворення органів місцевого самоврядування рад відповідного рівня, що становлять інтереси мешканців певної території, причому між радами різних рівнів відносини субординації відсутні. Першим кроком сучасних реформ в Україні стала адміністративно-територіальна реформа і, відповідно, створення об'єднаних територіальних громад (ОТГ) [4, с. 3].

Проте зазначимо, що громада виникає не природним шляхом, її цілеспрямовано створює місцеве співтовариство через процес зважених, планомірних i взаємозалежних дій, які враховують спільні інтереси різних сегментів локального суспільства. Довільне функціювання територіальних спільнот поселенської мережі без відчуття зв'язку і взаємодії місцевого населення, 